\title{
PENINGKATAN HASIL BELAJAR SISWA SMK NEGERI I PROVINSI SULAWESI SELATAN MELALUI PEMANFAATAN METODE QUANTUM LEARNING
}

\author{
Rusli Ismail \\ Jurusan Pendidikan Teknik Mesin Fakultas Teknik Universitas Negeri Makassar \\ E-Mail: rusli.ismail@unm.ac.id
}

\begin{abstract}
Abstrak
Penelitian ini merupakan penelitian tindakan kelas (Classroom Action research) yang bertujuan untuk meningkatkan hasil belajar Pengetahuan Dasar Teknik Mesin (PDTM) siswa SMK Negeri I Provinsi Sulawesi Selatan. Objek penelitian ini adalah siswa kelas XI Teknik Las SMK Negeri I Provinsi Sulawesi Selatan yang berjumlah 24 orang siswa,.Teknik pengumpulan data yang digunakan adalah melalui pemberian tes pada setiap akhir siklus sesuai dengan materi yang diajarkan sebelumnya pada setiap siklus dan obseravsi langsung pelaksanaan tindakan.Hasil penelitian ini mengidentifikasi adanya peningkatan hasil belajar siswa secara kuantitatif, peningkatan ini terlihat pada skor rata-rata hasil belajar siswa pada kelas XI Teknik Las SMK I Provinsi Sulawesi Selatan, untuk masisng kelas pengelasan. Di kelas pengelasan 1 tes awal sebesar 65 meningkat pada siklus I sebesar 71,45 yang kemudian dilanjutkan dengan tindakan siklus II sebesar 77,71. Di kelas pengelasan 2 diperoleh hasil tes awal 65,38 meningkat pada siklus I menjadi 71,75 dan pada siklus II meningkat dengan hasil tes 77,5. kelas pengelasan 3 tes awal diperoleh 69,64 meningkat pada siklus 2 sebesar 75,18 kemudian pada siklus II diperoleh hasil meningkat 81,07Secara kualitatif terjadi perubahan keaktifan dan perhatian siswa selama pelaksanaan tindakan yaitu meningkatnya keaktifan siswa dalam mengerjakan tugas-tugas, memupuk keberanian siswa dalam mengemukakan pendapat, serta terciptanya suatu kondisi proses pembelajaran yng menyenangkan bagi siswa SMK Negeri I Provinsi Sulawesi Selatan.
\end{abstract}

Kata Kunci: Quantum Learning, hasil belajar.

\begin{abstract}
This research is a class action research (Classroom Action research) which aims to improve learning outcomes of Mechanical Engineering Basic Knowledge (PDTM) for students of SMK Negeri I, South Sulawesi Province. The object of this research is the students of class XI of Las Teknik I of South Sulawesi Province, totaling 24 students. The data collection technique used is through the provision of tests at the end of each cycle in accordance with the material taught earlier in each cycle and direct observation of action implementation. The results of this study identified an increase in student learning outcomes quantitatively, this increase was seen in the average score of student learning outcomes in class XI of Las Teknik I of South Sulawesi Province, for the welding class. In the first class welding test of 65 increased in the first cycle of 71.45 which then continued with the action of the second cycle of 77.71. In welding class 2 the initial test results obtained 65.38 increased in the first cycle to 71.75 and in the second cycle increased with 77.5 test results. welding class 3 preliminary test obtained 69.64 increased in cycle 2 by 75.18 then in the second cycle obtained results increased 81.07 Qualitatively there was a change in the activeness and attention of students during the implementation of the action namely increasing student activity in doing assignments, fostering student courage in expressing opinions, as well as the creation of a favorable learning process condition for students of SMK Negeri I of South Sulawesi.
\end{abstract}

Keywords: Quantum Learning, learning outcomes. 


\section{PENDAHULUAN}

$\begin{array}{ccr}\text { Proses } & \text { belajar } & \begin{array}{r}\text { mengajar } \\ \text { merupakan }\end{array} \\ \text { serangkaian } & \text { kegiatan }\end{array}$ perbuatan guru dan siswa atas dasar hubungan timbal-balik yang berlangsung dalam situasi edukatif untuk mencapai tujuan tertentu. Dalam proses belajar mengajar guru memiliki peran yang sangat penting dalam membangkitkan motivasi siswa saat mengikuti pelajaran . Oleh karena itu, guru harus mampu mengembangkan keterampilanketerampilan dalam proses belajar mengajar.

Pengertian Quantum adalah interaksi yang mengubah energy menjadi cahaya, Quantum Learning ialah pengajaran yang dapat mengubah suasan belajar yang menyenangkan serta mengubah kemampuan dan bakat alamiah siswa menjadi cahaya yang akan bermanfaat bagi mereka sendiri dan bagi orang lain. Quantum learning perpaduan bermacam-macam interaksi yang di dalam dan di sekitar momen belajar, atau suatu pembelajaran yang mempunyai misi utama untuk merancang suatu proses belajar yang menyenangkan yang disesuaikan dengan tingkat perkembangan siswa. Interaksi-interaksi ini mencakup unsusr-unsur untuk belajar efektif yang mempengaruhi keberhasilan siswa.

Quantum Learning merupakan kiat, petunjuk strategi, dan seluruh proses belajar yang dapat mempertajam pemahaman dan daya ingat, serta membuat belajar sebagai suatu proses yang menyenangkan dan bermanfaat. Beberapa teknik yang dikemukakan merupakan teknik meningkatkan kemampuan diri yang sudah populer dan umum digunakan.

Di dalam Quantum Learning terdapat beberapa hal penting seperti siswa dikenalkan dengan "kekuatan pikiran" yang tak terbatas. Ditegaskan bahwa otak manusia mempunyai potensi yang sama dengan yang dimiliki oleh
Albert Einstein, selain itu dipaparkan tentang bukti fisik dan ilmiah yang menggambarkan bagaimana otak itu bekerja. Melalui hasil penelitian tentang Quantum Learning diperoleh bahwa proses belajar itu mirip bekerjanya otak seorang anak usia 6-7 tahun yang bagai spons menyerap berbagai fakta, sifat-sifat fisik, dan kerumitan bahasa yang kacau dengan cara menyenangkan dan bebas dari stress. Bagaimana factor-faktor umpan balik dan rangsangan dari lingkungan telah menciptakan kodisi yang sempurna untuk belajar apa saja.Hal ini menegaskan bahwa kegagalan dalam belajar bukan merupakan rintangan.

Rosyidi (2013) di dalam penelitiannya menemukan bahawa model Quantum Learning membantu media lingkungan lebih baik dari pada model pembelajaran konvensional terhdap motifasi dan prestasi belajar. Hasil penelitian lain Lilis (2013) mengemukakan bahwa adanya peningkatan motivasi belajar yang meliputi minat, kerjasama, keaktifan, dan suasana belajar akan lebih baik dengan menggunakan pendekatan model Quantum Learning .

belajar adalah perubahan tingkah laku dalam diri seseorang (individu) yang disebabkan oleh adanya suatu proses aktif yang terjadi melalui latihan dan pengalaman. Perubahan yang dimaksud di sini mencakup perubahan pengetahuan, hasil belajar, sikap dan tingkah laku, keterampilan, kecakapan, dan kemampuan perubahan aspek kualitas yang terjadi pada diri individu.

Tolak ukur keberhasilan proses pembelajaran dapat ditinjau dari proses dan hasil belajar yang dicapai siswa. Untuk mengukur tingkat keberhasilan proses belajar mengajar maka digunakan suatu penilaian. Penilaian adalah sebagai aktivitas dalam menentukan tinggi rendahnya hasil belajar itu sendiri. Hasil belajar merupakan informasi kuantitatif yang menunjukkan seberapa besarkah tingkat penguasaan materi yang telah 
diajarkan kepada siswa setelah proses belajar mengajar yang diperoleh melalui suatu penelitian.

Belajar adalah kemampuankemampuan yang dimiliki siswa setelah ia menerima pengalaman belajar. Benyamin Bloom (Anni, 2004:6) membagi hasil belajar menjadi tiga ranah yaitu:

1. Ranah kognitif, berkenaan dengan hasil belajar intelektual yang terdiri dari pengetahuan/ingatan, pemahaman, analisis, aplikasi, dan evaluasi. Kelima tujuan ini sifatnya hierarki, artinya kemampuan evaluasi belum tercapai bila kemampuan sebelumnya belum dikuasai.

2. Ranah afektif, berkenaan dengan sikap yang terdiri dari penerimaan, penanggapan, penilaian, pengorganisasian, dan pembentukan pola hidup.

3. Ranah psikomotorik, berkenaan dengan hasil belajar keterampilan dan kemampuan bertindak.

$$
\text { Untuk mencapai tujuan }
$$

pembelajaran PDTM yang efektif maka diperlukan metode pembelajaran yang tepat. Salah satu metode pembelajaran yang tepat adalah metode Quantum Learning. Dengan penerapan metode ini siswa mempelajari suatu bahan pelajaran dengan berusaha memahami makna atau artinya serta dengan perasaan nyaman dalam mengerjakan tugas maka siswa akan lebih mudah dalam menyelesaikan soal-soal yang berhubungan dengan materi yang diajarkan.

Masalah yang menjadi pusat perhatian dalam penelitian ini adalah seberapa besar peningkatan hasil belajar siswa pada mata diklat PDTM melalui metode pembelajaran Quantum Learning pada SMK Negeri I Provinsi Sulawesi Selatan

tujuan penelitian ini adalah untuk mengetahui seberapa besar peningkatan hasil belajar mata diklat PDTM melalui metode pembelajaran Quantum Learning pada SMK Negeri I Provinsi Sulawesi Selatan.

Hasil penelitian ini diharapkan dapat bermanfaat bagi: Bagi siswa, guru maupun kepala sekolah bagi siswa dapat meningkatkan hasil belajar mata diklat PDTM melalui metode pembelajaran Quantum Learning dan bagi guru, sebagai masukan dalam usaha meningkatkan hasil belajar serta mendapatkan cara yang efektif dalam penyajian pelajaran mata diklat PDTM khususnya dan mata diklat lain pada umumnya melalui metode pembelajaran Quantum Learning. Sedangkan bagi kepala sekolah, diharapkan penelitian ini bermanfaat dalam upaya pengembangan mutu dan hasil pembelajaran, sekaligus sebagai bahan pertimbangan agar pembelajaran dengan metode pembelajaran Quqntum Learning dapat diterapkan pada semua mata diklat.

\section{METODE PENELITIAN}

Penelitian ini tindakan kelas direncanakan dua siklus yaitu Siklus I dan Siklus II. Setiap siklus dilaksanakan sesuai dengan perubahan yang ingin dicapai antara Siklus I dengan Siklus II yang merupakan komponen yang saling berkaitan. Hubungan antara komponen pada Siklus I dengan komponen Siklus II dapat digambarkan sebagai berikut.

\section{Siklus I}

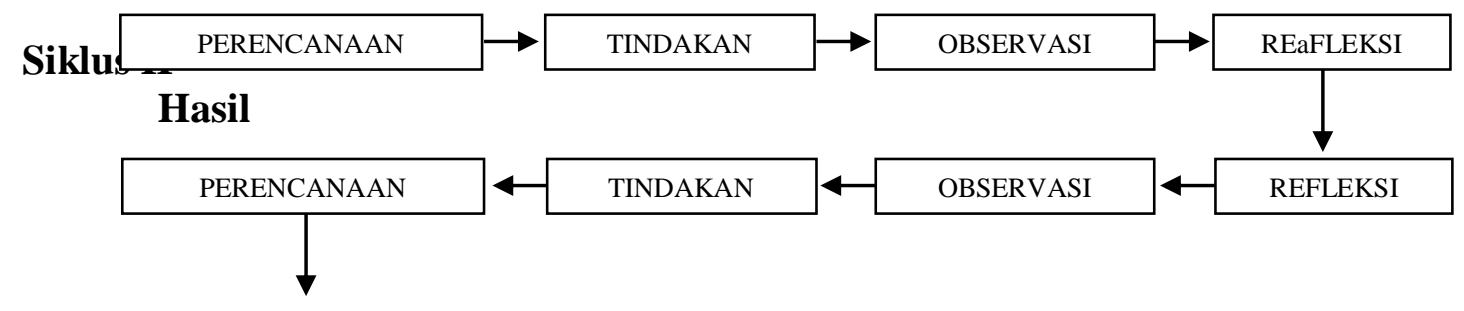


Berdasarkan skema di atas, maka prosedur kerja penelitian tindakan kelas ini sebagai berikut:

\section{Siklus I}

\section{Tahap perencanaan tindakan}

a. Peneliti bersama guru bidang studi mendiskusikan masalah-masalah berdasarkan hasil observasi yang dijumpai pada proses belajar mengajar.

b. Menentukan pokok bahasan yang akan diajarkan

c. Menyusun Rencana Pelaksanaan Pembelajaran (RPP)

d. Mendesain dan mengembangkan skenario pembelajaran dengan menggunakan metode resitasi, yaitu pemberian tugas yang dikerjakan dan dipertanggungjawabkan sendiri oleh siswa.

e. Mempersiapkan lembar observasi untuk mengamati aktivitas siswa selama berlangsungnya proses belajar mengajar.

f. Membuat tes Siklus I sebagai alat evaluasi untuk melihat apakah kemampuan siswa dalam menyelesaikan soal-soal berdasarkan materi yang diajarkan pada Siklus I.

2. Tahap pelaksanaan tindakan

a. Mempersiapkan semua perangkat pembelajaran yang akan digunakan dalam kelas

b. Menyajikan materi pelajaran secara singkat

c. Memberikan instrument atau tugas kepada siswa

d. Berkeliling memantau siswa selama mengrejakan tugas yang diberikan

e. Menunjuk siswa mempresentasekan jawaban atau maju di papan tulis mengerjakan hasil jawabannya disertai dengan bimbingan dari guru kemudian dibahas secara bersama

f. Memberikan tugas untuk dikerjakan di rumah yang akan dipertanggungjawabkan pada pertemuan berikutnya.

\section{Tahap observasi dan evaluasi}

Pada tahap ini ada dua perlakuan yaitu observasi dan evaluasi. Pelaksanaan tahap observasi terhadap aktivitas siswa selama berlangsung proses belajar mengajar yang menggunakan lembar observasi dengan tujuan melihat adanya peningkatan aktivitas belajar siswa dengan cara mengamati dan mencatat aktivitas siswa selama pelaksanaan proses belajar mengajar. Pelaksanaan evaluasi memberika tes hasil belajar yang dilakukan pada akhir tindakan Siklus I dengan tujuan untuk mengetahui peningkatan hasil belajar siswa.

\section{Analisi dan refleksi}

Hasil yang dicapai dalam tahap observasi dan evaluasi dikumpul kemudian dilakukan analisis dan refleksi. Refleksi dimaksud untuk melihat apakah rencana telah terlaksana secara optimal atau perlu dilakukan perbaikan. Aspekaspek yang dianggap bagus tetap dipertahankan,sedangkan

kekurangannnya menjadi pertimbangan dan revisi pada siklus berikutnya.

Jika pembelajaran pada Siklus I siswa belum mengalami peningkatan hasil belajar sesuai dengan yang diharapkan maka akan dilanjutkan ke Siklus II dengan tahapan-tahapan yang relatif sama dengan Siklus I

\section{TEKNIK PENGUMPULAN DAN ANALISIS DATA}

Adapun teknik pengumpulan data yang akan dilakukan dalam penelitian ini adalah sebagai berikut:

a. Data mengenai hasil belajar diambil dari tes tiap siklus. Tes tersebut dibuat oleh peneliti dalam bentuk soal pilihan ganda dan eesay

b. Data tentang aktivitas belajar mengajar diambil pada saat dilaksanakan tindakan dengan menggunakan lembar observasi.

Data yang diperoleh dari tes kemampuan dianalisis secara kuantitatif dengan menggunakan statistic deskriptif yaitu skor rata-rata, persentase, nilai minimum 
dan maksimum yang dicapai setiap siklus.

Adapun kriteria secara deskriptif yang digunakan setelah sampai pada persentase adalah pada Surat Edaran Direktorat Pendidikan Menengah Umum no. 2/C3/MN/1999 sebagai berikut:

Tabel 1. Kriteria Persentase pada surat edaran Direktorat Pendidikan Menengah

Umum N.288/C3/MN/1999

\begin{tabular}{|l|l|}
\hline Persentase $(\%)$ & Tingkat Penguasaan \\
\hline $0-34$ & Sangat rendah \\
$35-54$ & Rendah \\
$55-64$ & Sedang \\
$65-84$ & Tinggi \\
$85-100$ & Sangat tinggi \\
\hline
\end{tabular}

Menurut pertimbangan praktis, berdasarkan tingkat penguasaan teknik ketegori standar dengan skala lima yang ditetapkan oleh Departemen Pendidikan dan Kebudayaan Trianto (2007:23) pada tabel $1 \mathrm{di}$ atas dapat disederhanakan pada tabel 2 sebagai berikut ini: Tabel 2 . Teknik Ketegorisasi Standar Kelulusan
Belajar PDTM Melalui Penerapan Model Quantum Learning

\begin{tabular}{|l|l|}
\hline Skor Kuantitatif & Skor Kualitatif \\
\hline $0-69$ & Tidak Tuntas \\
$70-100$ & Tuntas \\
\hline
\end{tabular}

\section{HASIL PENELITIAN}

Hasil dan analisis data penelitian ini dibuat berdasarkan data yang diperoleh dari kegiatan penelitian tentang Pemanfaatan Metode Quantum Learning Untuk Meningkatkan Hasil Belajar Siswa SMK Negeri I Provinsi Sulawesi Selatan di Makassar. Pelaksanaan penelitian ini dilakukan selama 2 siklus.Adapun yang dianalisis adalah hasil tes awal, tes akhir siklus I dan siklus II, serta data tambahan berupa perubahan sikap siswa yang diambil dari hasil pengamatan maupun tanggapan yang diberikan siswa selama penelitian berlangsung. Hasil dan pembahasan yang diperoleh dari dua siklus selama penelitian ini adalah sebagai berikut:

Tabel 3.Deskriptif Hasil Belajar Siswa PDTM SMK Negeri I SulSel pada tes Siklus I.

\begin{tabular}{|l|l|l|l|l|l|l|l|}
\hline \multirow{2}{*}{ Kategori } & \multirow{2}{*}{ Skor } & \multicolumn{2}{l|}{ Kelas Pengelasan 1 } & \multicolumn{2}{l|}{ Kelas Pengelasan 2 } & \multicolumn{2}{l|}{ Kelas Pengelasan 3 } \\
\cline { 3 - 8 } & & Jumlah & Persen (\%) & Jumlah & Persen (\%) & Jumlah & Persen $(\%)$ \\
\hline Sangat Rendah & $0-34$ & - & - & - & - & - & - \\
\hline Rendah & $35-54$ & - & - & - & - & - & - \\
\hline Sedang & $55-64$ & 2 & 8,33 & - & - & 1 & 3,58 \\
\hline Tinggi & $65-84$ & 21 & 87,50 & 26 & 100 & 24 & 85,71 \\
\hline Sangat Tinggi & $85-100$ & 1 & 4,17 & - & - & 3 & 10,71 \\
\hline Jumlah & 24 & 100 & 26 & 100 & 28 & 100 \\
\hline
\end{tabular}

Berdasarkan table 3 menunjukkan bahwa dari 24 siswa kelas XI Teknik Las kelas pengelasan 1 , setelah pemberian Tes Siklus I diketahui, sebanyak 2 siswa dengan persentase $8,33 \%$ masuk dalam kategori sedang, 21 siswa dengan persentase $87,5 \%$ masuk dalam kategori tinggi, dan 1 siswa dengan persentase $4,17 \%$ masuk dalam kategori sangat tinggi.

Berdasarkan table 3 menunjukkan bahwa dari 26 siswa kelas XI Teknik Las kelas pengelasan 2, setelah pemberian
Tes Siklus I diketahui, sebanyak 26 siswa dengan persentase $100 \%$ masuk dalam kategori tinggi.

Berdasarkan table 3 menunjukkan bahwa dari 28 siswa kelas XI Teknik Las kelas pengelasan 3 , setelah pemberian Tes Siklus I diketahui, sebanyak 1 siswa dengan persentase $3,58 \%$ masuk dalam kategori sedang, 24 siswa dengan persentase $85,71 \%$ masuk dalam kategori tinggi, dan 3 siswa dengan persentase $10,71 \%$ masuk dalam kategori sangat tinggi. 
Tabel 4.Deskriptif Hasil Belajar Siswa PDTM SMK Negeri I SulSel pada tes Siklus II.

\begin{tabular}{|l|l|l|l|l|l|l|l|}
\hline \multirow{2}{*}{ Kategori } & \multirow{2}{*}{ Skor } & \multicolumn{2}{l|}{ Kelas pengelasan 1 } & \multicolumn{2}{l|}{ Kelas pengelasan 2 } & \multicolumn{2}{l|}{ Kelas Pengelasan 3 } \\
\cline { 3 - 8 } & & Jumlah & Persen (\%) & Jumlah & Persen (\%) & Jumlah & Persen $(\%)$ \\
\hline Sangat Rendah & $0-34$ & - & - & - & - & - & - \\
\hline Rendah & $35-54$ & - & - & - & - & - & - \\
\hline Sedang & $55-64$ & - & - & - & - & - & - \\
\hline Tinggi & $65-84$ & 15 & 62,5 & 20 & 76,92 & 15 & 53,57 \\
\hline Sangat Tinggi & $85-100$ & 9 & 37,5 & 6 & 23,08 & 13 & 46,43 \\
\hline Jumlah & 24 & 100 & 26 & 100 & 28 & 100 \\
\hline
\end{tabular}

Berdasarkan tabel 4 menunjukkan bahwa dari 24 siswa kelas XI Teknik Las pengelasan 1, setelah pemberian Tes Siklus II, sebanyak 15 siswa dengan persentase $62,5 \%$ masuk dalam kategori tinggi dan 9 siswa dengan persentase $37,5 \%$ masuk dalam kategori sangat tinggi. Berdasarkan tabel 4 menunjukkan bahwa dari 26 siswa kelas XI Teknik Las kelas pengelasan 2, setelah pemberian Tes Siklus II diketahui, sebanyak 20 siswa dengan persentase $76,92 \%$ masuk dalam kategori tinggi dan 6 siswa dengan persentase $23,08 \%$ masuk dalam kategori sangat tinggi.

Berdasarkan tabel 4 menunjukkan bahwa dari 28 siswa kelas XI Teknik Las kelas pengelasan 3 , setelah pemberian Tes Siklus II diketahui, sebanyak 15 siswa dengan persentase $53,57 \%$ masuk dalam kategori tinggi dan 13 siswa dengan persentase $46,43 \%$ masuk dalam kategori sangat tinggi. Nilai rata-rata kelas meningkat dari tiap siklus, disebabkan oleh meningkatnya keaktifan dan minat siswa dalam mengikuti kegiatan pembelajaran.Hal ini disebabkan kerena pembelajaran dengan metode Quantum Learning menitik beratkan pada siswa dimana semua siswa bertanggungjawab atas hasil kerjanya dan saling memotivasi dalam berprestasi.

\section{KESIMPULAN}

Berdasarkan hasil dari penelitian ini dan pembahasan maka dapat disimpulkan bahwa penggunaan model pembelajaran metode Quantum Learning dapat meningkatkan hasil belajar PDTM siswa kelas XI Teknik Las SMK Negeri I Provinsi Sulawesi Selatan, dimana pada tes awal nilai rata 65 meningkat 71,45 pada siklus I dan selanjutnya meningkat menjadi 77,7 pada siklus II

\section{DAFTAR PUSTAKA}

Abdul Haling. 2007. Belajar dan Pembelajaran. Universitas Negeri Makassar

Anni, Chatarina Tri. 2004. Psikologi Belajar. Semarang : UPT MKK UNNES

Dimyati, 2002. Belajar dan Pembelajaran. Jakarta: Rineka Cipta

Djamarah, 2003. Strategi Belajar Mengajar, Jakarta: Rineka Cipta

Imansyah. 1984. Didaktik Metode Pendidikan. Surabaya: Usaha Nasional

Purwanto. M.N. 1990. Psikologi Pendidikan. Bandung: PT Remaja Rosdakarya

Purwanto, M.N. 2006. Prinsip-prinsip dan Tekhnik Evaluasi Pembelajaran. Bandung: PT Remaja Rosdakarya

Sardiman, A.M. 1992. Interaksi dan Metode Belajar Mengajar. Jakarta : PT Raja Grafindo Persada

Slameto. 2003. Belajar dan Faktor-faktot yang Mempengaruhinya. Jakarta: Rineka Cipta

Sudirman. 1991. Ilmu Pendidikan. Bandung: Remaja Rosdakarya

Sudjana, N. 1996. Cara Belajar Siswa Aktif Dalam Proses Belajar Mengajar. Bandung: Sinar Baru Algensindo

Wiryawan. 1990. Strategi Belajar Mengajar. Departemen Pendidikan dan Kebudayaan. Universitas Terbuka Jakarta 